\title{
ANALISIS NILAI-NILAI BIMBINGAN DAN KONSELING DALAM BUDAYA PRA NIKAH SUKU KAILI PROVINSI SULAWESI TENGAH
}

\section{ANALYSIS OF THE VALUE OF GUIDANCE AND COUNSELING IN PRE-MARRIAGE CULTURE OF THE KAILI TRIBE, CENTRAL SULAWESI PROVINCE}

\author{
Rosmiati ${ }^{1}$ \\ Kementerian Agama \\ Kabupaten Gowa ${ }^{1}$ \\ email: \\ rosmiatikemenag@gma \\ il.com
}

IJI Publication p-ISSN: 2774-1907 e-ISSN: 2774-1915 Vol. 1, No. 3, pp. 253259, Juli 2021

\footnotetext{
in Unit Publikasi Ilmiah Intelektual Madani Indonesia
}

Abstrak: Penelitian ini bertujuan untuk menggali nilai-nilai bimbingan dan konseling dalam budaya pra nikah masyarakat Suku Kaili. Sebagaimana suku-suku lainnya, Suku Kaili juga mempunyai adat istiadat sebagai bagian kekayaan budaya didalam kehidupan sosial, memiliki hukum adat sebagai aturan dan norma yang harus dipatuhi, serta mempunyai aturan sanksi dalam hukum adat. Metode yang digunakan dalam penelitian ini adalah pendektan deskriptif kualitatif yang bertujuan untuk memperoleh pemahaman dan penafsiran mendalam tentang nilai-nilai budaya pernikahan Suku Kaili serta implikasi nilai-nilai budaya pernikahan suku kaili dalam layanan bimbingan dan konseling. Hasil penelitian menunjukkan bahwa nilai-nilai budaya pernikahan Suku Kaili dapat dijabarkan dalam tujuh prosesi sebelum pernikahan yaitu Notate Dala (mencari Informasi), Neduta atau Nebolai (Meminang), Noova (Penentuan waktu), Nanggeno Balanja (hantar belanja), Napasoa (pengasapan), Nogigi (membersihkan bulubulu), Nokolontigi dengan mengandung nilai yaitu pengenalan dan pencarian informasi, memahami diri dalam peminangan, tanggung jawab, mandiri dan amanah, kedewasaan dan aktualisasi diri.

Kata Kunci : Nilai Budaya, Bimbingan dan Konseling, Pra Nikah.

Abstract: This study aims to explore the values of guidance and counseling in the pre-marital culture of the Kaili Tribe. Like other tribes, the Kaili tribe also has customs as part of cultural wealth in social life, has customary law as rules and norms that must be obeyed, and has sanctions rules in customary law. The method used in this study is a qualitative descriptive approach which aims to gain an in-depth understanding and interpretation of the cultural values of Kaili marriages and the implications of the cultural values of Kaili marriages in guidance and counseling services. The results of the study showthat the cultural values of the Kaili Tribe can be described in seven pre-wedding processions, namely Notate Dala (seeking for information), Neduta or Nebolai (Making a hand), Noova (timing), Nanggeno Balanja (delivery of shopping), Napasoa (smoking), Nogigi ( cleaning the hairs), nokolontigi containing values, namely the introduction and search for information, self-understanding in a proposal, responsibility, independence and trustworthiness, maturity and self-actualization.

Keywords : Cultural Values, Guidance and Counseling, Pre-Marriage.

\section{PENDAHULUAN}

Negara Indonesia adalah negara kultural yang ditempati oleh masyarakat yang memiliki barmacam-macam kebudayaan. Kita selaku bangsa dan rakyat Indonesia seharusnya sadar akan pentingnya suatu kebudayaan, bukan hanya memahami, akan tetapi mulai mencoba untuk tetap melestarikan kebudayaan-kebudayaan yang ada. Kebudayaan berarti seperangkat norma yang dihayati oleh sekelompok masyarakat dan merupakan cara sekaligus pedoman dalam kehidupannya. Hal ini belajar dan lulus dari generasi tua yang baru, untuk dapat mentranfer secara efektif budaya dari suatu generasi ke generasi, maka harus diterjemahkan kedalam bentuk simbol. Bahasa, seni, dan agama berfungsi sebagai sarana simbolik transfer nilai-nilai budaya antar generasi.

Selain budaya negara Indonesia juga memiliki hukum yang merupakan alat untuk mengatur ketertiban masyarakat. Sehingga menurut Satjipta Rahardjo (1986) bahwa hukum selain berfungsi sebagai pengatur kehidupan masyarakat atau sosial kontrol, juga berfungsi sebagai pembentuk masyarakat. Kedua fungsi itu diharapkan berjalan serempak, dapat menjaga dan mengatur masyarakat agar tidak terpengaruh dan menjadi korban globalisasi. Salah satu yang dapat diatur oleh hukum adalah pelaksanaan perkawinan perkawinan harus diatur melalui hukum agar orang yang melaksanakannya dapat hidup tentram dan damai. Menurut Manan, (2002) perkawinan 
adalah ikatan lahir batin antara seorang pria dengan seorang wanita sebagai suami-istri dengan tujuan membentuk keluarga atau rumah tangga yang bahagia, kekal dan harmonis.

Suku Kaili adalah suku bangsa di Indonesia yang secara turun-temurun tersebar mendiami sebagian besar dari Provinsi Sulawesi Tengah. Etnis Kaili yang memiliki populasi terbesar dan tersebar di lima wilayah Daerah Tingkat II, yaitu Kota Palu, Kabupaten Donggala, Kabupaten Parigi Moutong (Parimo), sebagian di Kabupaten Poso dan belakangan Kabupaten Sigi Biromaru. Penyebaran suku ini terkait dengan tradisi adat dimasa lalu dari kaum bangsawan yang menyebarkan keturunannya ke daerah lain melalui cara perkawinan (tradisi ada nasibolai). Suku Kaili memiliki keunikan tersendiri dimana pada suku kaili prosesi pernikahan itubertahap yang dimulai dengan prosesi notate dala sampai pada saat mopatuda. Itulah keunikan Suku Kaili d banding dengan suku-suku lainnya.

Pada masyarakat Kaili sebelum melakukan pernikahan mereka melakukan adat peminangan, menurut Hermin (2001) peminangan yang disebut Neduta atau Nebolai dalam bahasa Suku Kaili adalah merupakan rangkaian prosesi adat yang harus dilewati oleh setiap anggota masyarakat yang ingin melangsungkan perkawinan. Budaya pernikahan Suku Kaili erat kaitannya dengan bimbingan konseling keluarga, seperti pengenalan dan pencarian informasi, memahami diri dalam peminangan, tanggungjawab, mandiri dan manah dan juga kedewasaan dan aktualisasi diri.

Hal ini sejalan dengan sasaran bimbingan konseling di luar sekolah meliputi semua individu dan kelompok, anggota keluarga dari berbagai lapisan dan lingkungan masyarakat, para pekerja dan juga warga masyarakat pada umumnya, yang semuanya hendak mengambangkan diri secara optimal dan menjalani kehidupan dengan bahagia.
Bimbingan konseling hendaknya lebih berpangkal pada nilai-nilai budaya yang secara nyata mampu mewujudkan kehidupan yang harmoni dalam kondisi pluralistik, satu hal yang perlu diingat dalam usaha bimbingan dan konseling yaitu bahwa usaha itu harus didasarkan pada norma-norma yang berlaku, norma agama, adat, maupun norma negara (hukum). Tujuan dan pelaksanaan pelayanan bimbingan tidak boleh menyimpang dari norma-norma yang berlaku di masyarakat.

Natawidjaja (Yusuf dan Juntika, 2008) mengartikan bimbingan dan konseling sebagai suatu proses pemberian bantuan kepada individu yang dilakukan secara berkesinambungan, supaya individu dapat memahami dirinya, sehingga sanggup mengarahkan dirinya dan dapat bertindak secara wajar, sesuai dengan tuntutan dan keadaan lingkungan sekolah, keluarga, masyarakat, dan kehidupan pada umumnya. Bimbingan dan konseling membantu individu mencapai perkembangan diri secara optimal sebagai makhluk sosial.

Suriyati (2013) mengemukakan bahwa secara umum sasaran dari bimbingan adalah mengembangkan apa yang terdapat pada diri tiap individu secara optimal agar setiap individu bias berguna bagi dirinya sendiri, lingkungannya dan masyarakat pada umumnya. Hal ini sejalan dengan kabutuhan tiap manusia untuk mengembangkan diri dalam bentuk aktualisasi diri di lingkungannya. Budaya Suku Kaili sebagai salah satu wujud jati diri budaya masyarakat palu memiliki peran penting dan relevan dengan upaya pembentukan karakter. Secara umum tujuan pelaksanaan budaya kaili sejalan dengan sasaran bimbingan dan konseling yaitu untuk mengenal, memahami dan mengembangkan diri tiap individu secara optimal sehingga mampu bermanfaat bagi dirinya sendiri, masyarakat, dan lingkungannya. Hal itu menjadikan peneliti untuk tertarik menganalisis nilai-nilai budaya 
pernikahan suku kaili yang dijalankan oleh masyarakat Palu dan selanjutnya mengkaji lebih mendalam tentang nilai-nilai bimbingan konseling dalam budaya pernikahan Suku Kaili.

\section{METODE}

Metode yang digunakan dalam penelitian ini adalah deskriptif kualitatif yang bertujuan untuk memperoleh pemahaman dan penafsiran mendalam tentang nilai-nilai budaya pernikahan Suku Kaili serta implikasi nilai-nilai budaya pernikahan Suku Kaili dalam layanan bimbingan dan konseling. Penelitian kualitatif merupakan jenis penelitian yang menghasilkan data tertulis atau lisan dari orang atau perilaku yang diamati. Pendekatan kualitatif yang dimaksudkan adalah bertujuan untuk mengungkapkan gejala-gejala menyeluruh melalui pengumpulan data sebagai sumber instrumen.

Moleong (2002) mengemukakan bahwa kualitatif menyajikan secara langsung hakikat penelitian dengan sumber data. Karena itu, pnelitian ini tidak berangkat dari satu kesimpulan sementara untuk diuji keberlakuannya di lapangan, melainkan peneliti meneliti di lapangan dan mengumpulkan data selengkap mungkin sesuai dengan fokus penelitian.

\section{HASIL DAN DISKUSI}

Bimbingan dalam keluarga adalah suatu proses pemberian bantuan kepada individu secara berkelanjutan dan sistematis yang dilakukan oleh seorang ahli yang telah mendapat latihan khusus untuk itu, dimaksudkan agar individu dapat memahami dirinya lingkungan keluarganya serta dapat mengarahkan diri dengan baik dalam menyesuaikan diri dengan lingkungan untuk dapat mengembangkan potensi dirnya secara optimal.

Proses bimbingan dan konseling tentunya melibatkan anggota masyarakat, lingkungan, dan kebudayaan yang ada. Nilainilai bimbingan dan konseling yang diterapkan di Indonesia belum banyak mengembangkan budaya lokal sebagai sumber pengembangan baru. Padahal kebudayaan sebagai suatu proses yang menjangkau semua kehidupan masyarakat memegang peran yang penting dan sebagai generasi muda kita wajib untuk mempelajari, menghubungkan nilai budaya yang dipelajari untuk selanjutnya dikembangkan ke generasi yang akan datang.

Dari beberapa rangkaian acara proses adat pernikahan Suku Kaili tersebut, yaitu pembelajaran dan bimbingan dan juga pengetahuan bagi calon pengantin, dan juga bagi remaja yang nantinya akan melakukan pernikahan dan secara umum tujuan pelaksanaan dari prosesi adat pernikahan Suku Kaili sejalan dengan sasaran bimbingan dan konseling yaitu untuk mengenal, memahami dan mengembangkan diri tiap individu secara optimal sehingga bermanfaat bagi dirinya, masyarakat dan lingkungannya.

\section{Proses Pra Nikah Masyarakat Suku Kaili}

Budaya pernikahan Suku Kaili sebagai salah satu falsafah hidup masyarakat Sulawesi Tengah khususnya masyarakat Palu, mengajarkan kepada para remaja untuk mengenali dirinya, dan mengenali kodratnya sebagai seorang wanita, calon istri dan calon suami serta mampu bertanggung jawab dalam lingkungan keluarga dan masyarakat. Prosesi budaya Kaili terdiri dari prosesi sebelum upacara pernikahan dan prosesi upacara pernikahan. Prosesi pra-nikah terdiri dari tujuh langkah yakni: 1) Notate Dala (mencari informasi), 2) Neduta atau Nebolai (meminang), 3) Noovo, (penentuan waktu), 4) Nanggeni Balanja (hantar belanja), 5. Nopasoa (pengasapan), 6) Nogigi (membersihkan bulu wajah), 7) Nokolontigi. Pada masyarakat kaili sebelum melakukan upacara pernikahan adat beberapa proses rangkaian pelaksanaan upacara adat suku kaili tersebut antara lain : 
1) Notate Dala (Mencari Informasi)

Proses ini merupakan rangkaian dari pemilihan jodoh, karena bila sudah ditentukan pilihan dan mendapat persetujuan dari kedua orang tua, maka diadakanlah musyawarah untuk mencari informasi keberadaan siwanita yang dimaksud menyangkut masalah status keterikatannya. Bila siwanita tersebut tidak terikat dengan pria lain, maka diutuslah seorang yang dipercaya (pemuka adat) untuk mengadakan pendekatan informal kepada keluarga wanita tersebut. Karena pertemuan itu sangat rahasia, maka maksud kedatangan utusan laki-laki itu hanya diucapkan lewat kiasan.

2) Neduta atau Nebolai (Meminang)

Dalam konsep pemahaman masyarakat suku Kaili, meminang mempunyai dua makna yang sama, namun dalam penggunaannya yang berbeda sesuai dengan tingkat strata sosial masyarakat bersangkutan. Neduta adalah istilah meminang yang diperuntukkan bagi golongan biasa, sedangkan Nebolai adalah istilah meminang digunakan untuk golongan bangsawan. Dari kedua konsep tersebut mempunyai konteks yang sama yakni melakukan lamaran kepada seorang gadis untuk dijodohkan atau dikawinkan kepada laki-laki yang melakukan lamaran.

3) Noovo (Penentuan Waktu)

Noovo adalah suatu rangkaian upacara yang dilakukan untuk membicarakan hal-hal yang berhubungan dengan upacara perkawinan, baik yang berhubungan dengan pelaksanaan pesta (eo mata posusa) maupun dari pernikahan (eo mponikah). Pelaksanaan upacara noovo ini dimaksudkan untuk mencari kesepakatan tentang hari pelaksanaannya, sebab biasa terjadi kesalahpahaman hanya karena persoalan waktu sehingga perlu kesepakatan. Di dalam pertemuan tersebut para pemuka atau tokoh adat akan memilih hari dan bulan yang sangat baik, sebab pada umumnya masyarakat Suku Kaili masih ketat dan percaya adanya hari dan bulan yang baik berdasarkan perhitungan cara tradisional dengan mempergunakan kutika, namun tetap mempertimbangkan jangka waktu bagi kesiapan wanita karena pada dasarnya pusat suatu kegiatan berada di pihak perempuan.

4) Nanggeni Balanja (Hantar Belanja)

Mengantar belanja masih merupakan rangkaian dari proses pelaksanaan suatu upacara perkawinan yang dilakukan pihak laki-laki untuk mengantar belanja. Di dalam pelaksanaan ini dipimpin seorang tokoh atau yang dituakan di samping orang-orang lainnya.

5) Nopasoa (Pengasapan)

Nopasoa merupakan mandi dengan sistem penguapan dan pengasapan yang dilakukan secara tradisional yang pada umumnya dilaksanakan di rumah calon pengantin wanita, yang bertujuan untuk menghilangkan bau badan sekaligus untuk mempercantik dan menyegarkan para calon pengantin, karena mempergunakan ramuan tradisional sebagai bahan yang digunakan dalam mandi uap tersebut.

6) Nogigi (Membersihkan Bulu Wajah)

Nogigi merupakan salah satu rangkaian dari proses pelaksanaan suatu acara sebelum akad-nikah, yakni mencukur bulu-bulu yang nampak, karena ada suatu anggapan yang berkembang dalam masyarakat Suku Kaili bahwa bulu-bulu tersebut sebagai bulu celaka (vulu cilaka). Kerelaan mereka mengeluarkan bulu bertujuan untuk mempercantik diri dan juga mengandung makna simbolik sebagai manifestasi dari sikap ketaatan dan keyakinannya untuk meninggalkan semasa perbuatan masa lalunya, dan siap untuk menghadapi masa depannya penuh dengan ketabahan.

7) Nokolontigi

Nokolontigi dimaksudkan untuk mensucikan diri sebelum menikah. Acara yang dilaksanakan pada malam hari ini dilakukan di rumah calon pengantin perempuan oleh para orangtua atau tokoh 
adat yang dianggap mempunyai garis keturunan baik-baik karena dengan demikian nantinya diharapkan calon pengantin juga akan mempunyai garis kehidupan seperti itu. Proses acara ini dimaksudkan agar kedua calon pengantin tidak dapat dipengaruhi rohroh jahat serta dapat terhindar dari bahaya, mudah rezeki dan mempunyai umur yang panjang.

\section{Nilai Bimbingan dan Konseling dalam Budaya Pra Nikah Suku Kaili}

Pendekatan bimbingan dan konseling sangat memperhatikan budaya karena klien sebagai individu pada dasarnya merupakan produk lingkungan budaya dimana dia hidup. Kebudayaan akan bimbingan timbul karena terdapat faktor yang menambah rumitnya keadaan masyarakat dimana individu itu hidup dan remaja sebagai sasaran budaya pernikahan suku kaili adalah bagian dari masyarakat tersebut.

Hal tersebut sejalan dengan pendapat Corey (Suryahadikusumah, 2012) bahwa konselor yang efektif adalah yang mampu menyiasati perbedaan budaya, mampu menerima dan menyampaikan pesan baik verbal maupun non verbal secara akurat, serta bertindak sebagai agen pembaruan. Kemampuan konselor dalam memanfaatkan perkembangan teknologi sebagai sarana pengelolaan informasi dalam kegiatan bimbingan dan konseling akan membuat layanan bimbingan dan konseling lebih efektif dan efisien.

Layanan bimbingan keluarga misalnya, konselor harus mampu dan bisa membantu individu agar individu mampu memahami dirinya, lingkungan keluarganya, serta dapat mengarahkan dirinya, lingkungan keluarganya, serta dapat mengarahkan dirinya dengan baik dalam menyesuaikan diri dengan lingkungan untuk dapat mengembangkan potensi dirinya secara optimal untuk kesejahteraan dirinya, kesejahteraan masyarakat, khususnya untuk kesejahteraan keluarganya.

Seluruh rangkaian upacara pernikahan suku kaili mulai dari Notate Dala sampai dengan prosesi Mopatuda memberikan pelajaran kepada calon pengantin agar memahami diri dalam peminangan, tanggung jawab, mandiri, amanah, kedewasaan dan aktualisasi diri, serta memberikan kekuatan kepada calon pengantin agar tidak mudah dipengaruhi oleh setan atau roh-roh jahat. Memberikan makna dan arti simbolik bagi keduanya tentang ancaman bila terjadi perceraian. Setelah semua prosesi selasai maka calon pengantin dianggap telah memahami seluk-beluk kehidupan dunia khususnya yang berkaitan dengan kehidupan rumah tangga. Prosesi ini menjadi modal utama pembentukan keluarga sakinah mawaddah warahma.

\section{Tabel 1}

Kaitan Nilai Budaya Suku Kaili Dengan Konseling Keluarga

Nilai-Nilai Budaya Suku Kaili Bimbingan Konseling Keluarga

- Pengenalan dan Tujuan bimbingan pencarian informasi konseling keluarga,

- Memahami diri dalam memberikan bantuan peminangan

- Tanggung jawab

- Saling menghargai, toleransi

- Mandiri dan amanah

Kedewasaan dan

aktualisasi

- Memahami dan menerima

Sumber: Data Sekunder 2020 kepada individu agar mereka mampu menciptakan keluarga yang utuh dan harmonis, memberdayakan diri dalam produktif, mandiri, dan bertanggung jawab.

Bimbingan konseling keluarga sejalan dengan nilai-nilai dalam prosesi pernikahan Suku Kaili, bimbingan untuk menghargai, toleransi, tanggung jawab terwujud dalam prosesi pengantaran belanja (Naggemo belanja), dan juga menentukan hari (Noova). Dimana proses ini keluarga pihak pengantin laki-laki mengantarkan belanja kepada pihak perempuan sekaligus menyerahkan isi sambulugana. Dan juga dalam kesempatan tersebut kedua keluarga berembuk menentukan hari yang baik untuk melangsungkan pernikahan. Nilai bimbingan 
konseling terdapat dalam prosesi tersebut yaitu saling menghargai, toleransi dan komunikasi yang penuh pengertian serta besarnya tanggung jawab yang akan dibebankan kepada kedua belah pihak baik laki-laki maupun perempuan setelah jadi suami dan istri.

Individu atau remaja dalam hal ini calon pengantin yang telah memiliki pemahaman tentang nilai-nilai yang terkandung dalam prosesi pernikahan suku kaili seperti mandiri, tanggung jawab, menghargai, toleransi, amanah dan juga kedewasaan dan yang lain-lainnya maka secara tidak langsung akan paham perannya dalam keluarga, lembaga pendidikan dan juga dalam masyarakat. Berikut disajikan table nilai-nilai bimbingan konseling dalam pranikah masyarakat Suku Kaili :

Tabel 2

Nilai Bimbingan dan Konseling dalam Pra Nikah Suku Kaili

\begin{tabular}{lll}
$\begin{array}{c}\text { Prosesi Budaya } \\
\text { Suku Kaili }\end{array}$ & Nilai-Nilai BK & $\begin{array}{c}\text { Bidang } \\
\text { Bimbingan \& } \\
\text { Konseling }\end{array}$ \\
\hline $\begin{array}{c}\text { 1. Notate } \\
\text { Dala }\end{array}$ & $\begin{array}{l}\text { pengenalan dan } \\
\text { 2. Nedute }\end{array}$ & \\
atau & - Memarian & \\
Nebolai & dalam & \\
3. Noova & peminangan & Keluarga \\
4. Nanggeno & - Tanggung jawab & \\
Belanja & - Mandiri dan & \\
5. Napasoa & amanah & \\
6. Nogigi & - Kedewasaan dan & \\
7. Nokolontigi & aktualisasi diri & \\
\hline
\end{tabular}

Sumber : Data Sekunder 2020

Prosesi dalam pernikahan Suku Kaili yaitu Notate Dala, Neduta atau Nebolai, Noova,Nanggeno Balanja, Napasoa, Nogigi, Nokolontigi mengajarkan kepada para remaja untuk menjaga rahasia (amanah) dan menjaga hubungan yang baik, pengenalan dan pencarian informasi, memahami diri dalam peminangan, tanggung Jawab, Mandiri dan amanah, kedewasaan dan aktualisasi diri, dari proses ini diharapkan seorang perempuan mampu mengenal dirinya.

Individu yang dihadapi dalam bimbingan dan konseling adalah individu yang hidup dalam masyarakat. Oleh karena itu, dalam memandang individu tidak pernah terlepas dari masyarakat beserta latar belakang sosial, dan kebudayaan. Hal ini menimbulkan adanya dinamika yang dapat memunculkan masalah bilah tidak ada pemahaman diri individu tersebut. Untuk itulah bimbingan hadir membantu individu agar mampu memahami diri serta lingkungannya.

Nilai-nilai bimbingan dan konseling yang terkandung dalam pernikahan suku kaili secara keseluruhan lebih banyak terkait dengan nila-nilai pada bidang bimbingan keluarga, dimana bimbingan konseling keluarga yaitu membantu anggota keluarga menerima kenyataan bahwa bila salah satu anggota keluarga mengalami masalah dia akan dapat memberikan pengaruh baik pada persepsi, harapan, maupun interaksi antara anggota keluarga yang lain.

\section{KESIMPULAN}

Berdasarkan hasil penelitian dan pemahaman yang telah diuraikan sebelumnya, maka dapat disimpulkan bahwa Nilai-nilai budaya pernikahan Suku Kaili dapat dijabarkan dalam tujuh prosesi sebelum pernikahan yaitu Notate Dala (mencari Informasi), Neduta atau Nebolai (Meminang), Noova (Penentuan waktu), Nanggeno Balanja (hantar belanja), Napasoa (pengasapan), Nogigi (membersihkan bulu-bulu), Nokolontigi dengan mengandung nilai yaitu pengenalan dan pencarian informasi, memahami diri dalam peminangan, tanggung jawab, mandiri dan amanah, kedewasaan dan aktualisasi diri.

\section{REFERENCE}

Manan , Abdul. (2002). Pokok- Pokok Hukum Perdata, Wewenang Pengadilan Agama. Jakarta: Rajagrafindo Persada

Moleong, Lexy. (2002). Metodologi Penelitian Kualitatif. Bandung: PT. remaja Rosdakarya. 
Hermin. (2001). Upacara Adat Perkawinan Suku Kaili. Palu: Dinas Kebudayaan dan Pariwisata Bagian Proyek Pembinaan Permuseuman Sulawesi Tengah.

Yusuf, S \& Juntika, N. (2008). Landasan Bimbingan dan Konseling. Bandung: Remaja Rosdakarya

Suryati. (2013). Pengaruh Bimbingan Karir Dan Persepsi Siswa Tentang Pendidikan Tekhnologi Kejuruan Pada SMPN 1 Jalan Cagak Kabupaten Subang. (Tesis) Universitas Pendidikan Indonesia.

Suryahadikusuma, A.R. (2012). Layanan Informasi dan Konsultasi Bimbingan dan Konseling Melalui Siaran Radio. Jurnal Pendidikan Universitas Pendidikan Indonesia (online). (htpp://www:repositury.upi.edu/Ahma d Rofi Suryadikusuma.pdf.

Rahardjo, Satjipto. (1986). Hukum dan Masyarakat. Angkasa, Bandung. 